\title{
Effect of Centella asiatica Leaves on Gastric Ulcer in Rats
}

\author{
Ester Mariska ${ }^{1}$, Trully D. Sitorus ${ }^{2}$, Januarsih A. Rachman ${ }^{3}$ \\ ${ }^{1}$ Faculty of Medicine, Universitas Padjadjaran, ${ }^{2}$ Department of Pharmacology and Therapy, \\ Faculty of Medicine, Universitas Padjadjaran, ${ }^{3}$ Department of Biology Cell, Faculty of Medicine, \\ Universitas Padjadjaran, Bandung, Indonesia
}

\begin{abstract}
Background: Gastric ulcer is disruption of gastric mucosal integrity due to lack of smaller defensive factors (e.g. mucus levels) than gastric aggressive factors. Centella asiatica is a traditional medicine that contains triterpenoids and flavonoids. The objective of this study was to analyze the effect of ethanol extract of Centella asiatica leaves for preventing gastric mucus level reduction of aspirin-induced gastric ulcer model in rats and compared it to misoprostol.

Methods: An experimental laboratory study using 24 rats that were divided into 4 groups. Group I (negative control) received carboxymethy cellulose (CMC) solution, group II (positive control) received CMC and aspirin $450 \mathrm{mg} / \mathrm{kg}$, group III (tested group) received Centella asiatica $400 \mathrm{mg} / \mathrm{kg}$ and aspirin $450 \mathrm{mg} / \mathrm{kg}$, group IV (compared group) received misoprostol $72 \mu \mathrm{g} / \mathrm{kg}$ and aspirin $450 \mathrm{mg} / \mathrm{kg}$ for three days. Then the rats were laparatomied and their gastric mucus levels were measured. The results were statistically analyzed by Independent T-test.

Results: The mean levels of gastric mucus of group I, II, III, IV, respectively were $0.112 ; 0.035 ; 0.537 ; 0.455$ optical densities per gram of tissue. The statistical test suggested a significant difference between the positive control group and tested group. Moreover there is no significant difference between the tested group and compared group.

Conclusions: Centella asiatica leaves can prevent gastric mucus level reduction of aspirin-induced gastric ulcer model in rats and has similar effect in gastric mucus level with misoprostol.
\end{abstract}

Keywords: Centella asiatica, gastric mucus, gastric ulcer, misoprostol

\section{Introduction}

Gastric ulcer is disruption of gastric mucosal integrityand arises from the smaller level of defensive factors (e.g. mucus levels) than gastric aggressive factors.1This condition can be triggered by the use of aspirin as anti-inflammatory and antiplatelet over a long period of time.

Patients with gastric ulcers often complain of epigastric pain, burning sensation, nausea, and vomiting. The pain arises after eating. This situation led to decreased patient's productivity. Therefore, the patients require treatments which may include modern medicine, such as misoprostol, or traditional medicine. The mechanism of action of misoprostol as a prostaglandin analogue is stimulating the secretion of mucus and bicarbonate, reducing mucosal cell turnover, and increasing mucosal blood flow. ${ }^{1}$
Traditional medicines have been used for treatment from generation to generation based on experiences. ${ }^{2}$ The percentage of Indonesian population who use traditional medicine is about $22.26 \%$ in $2008 .^{3}$ Traditional medicine is medicine derived from plants, animals, minerals, or a mixture of these materials. One of these traditional medicines is Centella asiatica.

Centella asiatica is a short-stemmed creeping plant that have been used as a cure for leprosy, syphilis, fever, and plays a role in wound healing, increasing work capacity of neurotransmitters in the brain, and revitalizing body tissues. It grows in tropical and subtropical regions, e.g. Indonesia. Centella asiatica has branched tap root, green leaves in a fan-shaped or kidney-shaped, round flowers, and small fruits. The height of Centella asiatica is $10-50 \mathrm{~cm}^{4}$

The objective of this study was to analyze the effect of Centella asiatica against gastric

Correspondence: Ester Mariska, Faculty of Medicine, Universitas Padjadjaran, Jalan Raya Bandung-Sumedang Km.21, Jatinangor, Sumedang, Indonesia, Phone: +62 81386841321 Email: ester_mariska@yahoo.com 


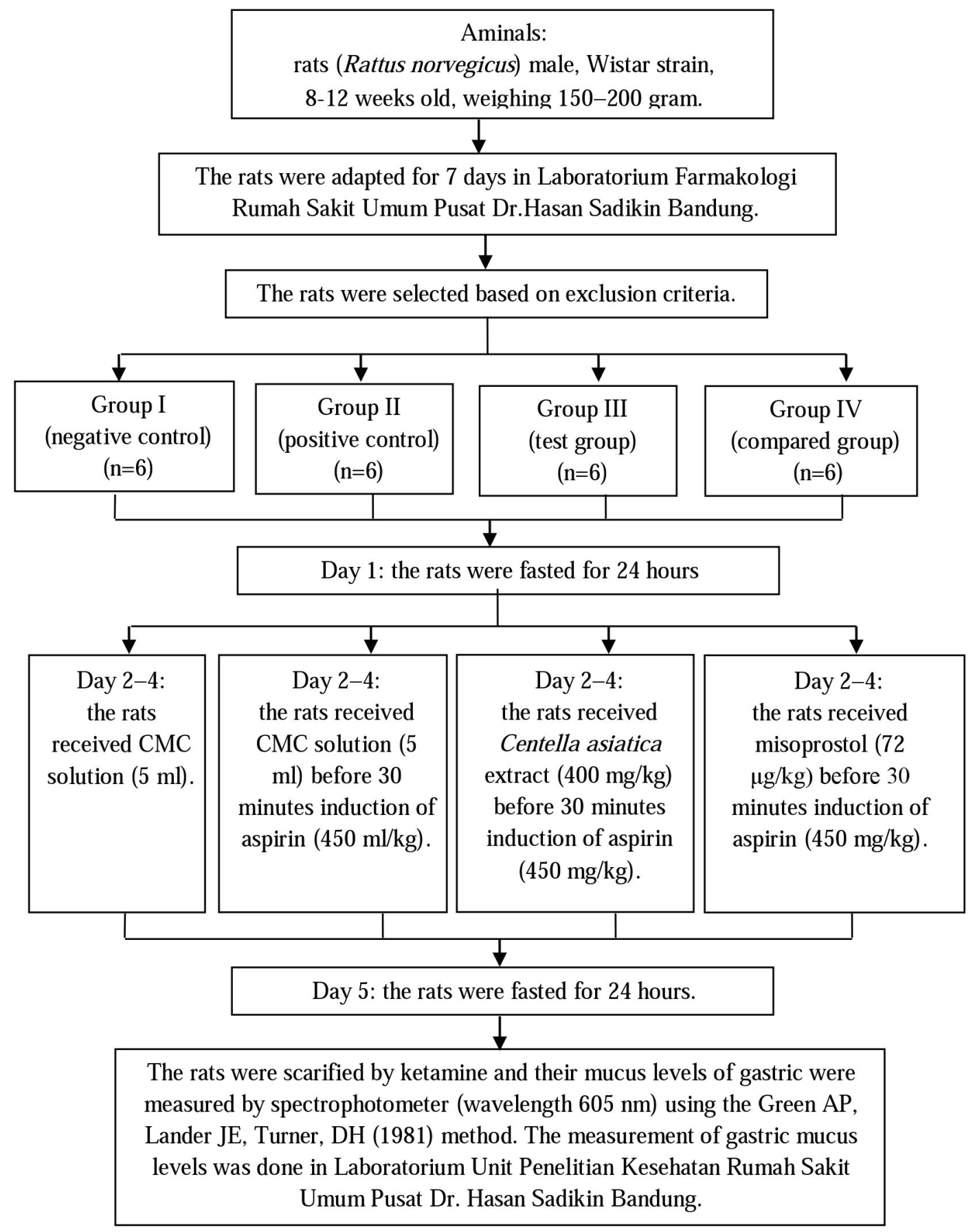

Figure 1 Procedures of The Experiment

ulcers and to compare the effect of Centella asiatica with misoprostol.

\section{Methods}

An experimental study was carried out, using
24 male wistar strain rats with inclusion criterias as follows: 8-12 weeks old, 150-200 grams weight, active movement, clean hair, no wound on the body, and normal stools. The exclusion criteria are weight lost more than $10 \%$ of the initial body weight during the 
adaptation and sickness after the adaptation. The rats were obtained from the Laboratory of Sekolah Ilmu Teknologi Hayati Institut Teknologi Bandung and were adapted for seven days in the Pharmacological Laboratory of Dr.Hasan Sadikin General Hospital Bandung to prevent or minimize the stress in a new environment. ${ }^{5}$ The leaves of Centella asiatica were obtained from Kebun Percobaan Manoko, Kecamatan Lembang, West Bandung, West Java and extracted in Balai Penelitian Tanaman Rempah dan Obat, Bogor, West Java. The fresh leaves were harvested at the age of 3-6 months. The leaves were sorted and washed to clean from dirt or foreign material and reduce from microbial. Then, the leaves were pulverized. Next, the sample was mixed with ethanol $(70 \%)$ with a ratio of $1: 5$ in shaking water bath for 3 hours and allowed to steady for 16 hours. The sample was filtered by filter paper, concentrated in a rotatory evaporator at $500 \mathrm{C}$ for 6 hours, and dried with a freezer dryer for 2 days. Twenty kg of wet Centella asiatica plant (all parts) became 836.5 grams of dried leaves and became 96 grams of dried extract. The dose of extract was $400 \mathrm{mg} / \mathrm{kg}$ body weight. ${ }^{6}$

Misoprostol was used as a comparative drug and obtained from PT Novell Pharmaceutical Laboratories. Misoprostol as a prostaglandin analogue has mechanisms of action for stimulating the secretion of mucus and bicarbonate, reducing mucosal cell turnover, and increasing mucosal blood flow. ${ }^{1}$ The dose of misoprostol was $72 \mu \mathrm{g} / \mathrm{kg}$ body weight. In this study, Aspirin was used to create a gastric ulcer condition in the rats and was obtained from PT Bayer Indonesia. Aspirin belongs to a class of Nonsteroidal Anti-inflammatory Drugs (NSAIDs). Mechanism of action of NSAIDs is to inhibit synthesis of prostaglandin. This mechanism can harm mucosal defense and repair, as well as stimulating mucosal damage. The NSAIDs are weak acids. The NSAIDs will remain as non-ionized lipophilic form if NSAIDs are in acidic environment. In that condition, NSAIDs will cross through the lipid membranes of epithelial cells and be trapped in the cell. If the drugs are trapped inside the cell, then the cell will be damaged. ${ }^{1}$ The dose of aspirin was $450 \mathrm{mg} / \mathrm{kg}$ body weight. The doses used in this study were the results from conversion using table experimental animals and humans. ${ }^{7}$ Centella asiatica extracts, aspirin, and misoprostol were dissolved in 5 $\mathrm{ml} \mathrm{CMC} \mathrm{solution} \mathrm{and} \mathrm{given} \mathrm{orally} \mathrm{to} \mathrm{the} \mathrm{rats.}{ }^{8}$

The rats were divided into 4 groups. Group I (negative control) received carboxymethy cellulose (CMC) solution, group II (positive control) received CMC and aspirin $450 \mathrm{mg} /$ $\mathrm{kg}$, group III (tested group) received Centella asiatica $400 \mathrm{mg} / \mathrm{kg}$ and aspirin $450 \mathrm{mg} /$ $\mathrm{kg}$, group IV (compared group) received misoprostol $72 \mu \mathrm{g} / \mathrm{kg}$ and aspirin $450 \mathrm{mg} / \mathrm{kg}$ during three days. The function of group I was to determine the normal gastric mucus level in rats. After 3 days, all the rats were scarified by ketamine and were laparatomied. Their gastric mucus levels were collected and measured by spectrophotometer (wavelength $605 \mathrm{~nm}$ ) using the Green AP, Lander JE, Turner, DH (1981) method. The measurement of gastric mucus levels was done in the Laboratory of Unit Penelitian Kesehatan Rumah Sakit Umum Pusat Dr. Hasan Sadikin Bandung. The results were analyzed using Independent T-test. The test in this study used Confidence interval (CI) 95\% ( $\alpha=5 \%)$.

The procedures were based on the research of M. Sancar et. al. (2009). ${ }^{9}$ The measurement of mucus levels were based on the Green AP, Lander JE, TurnerDH (1981) method. ${ }^{10}$ (Figure 1)

Table 1 Gastric Mucus Levels of the Gastric Ulcer Induced Rats

\begin{tabular}{ccccc}
\hline \multirow{2}{*}{ Group } & \multicolumn{4}{c}{ Gastric Mucus Level (optical density units per gram of tissue) } \\
\cline { 2 - 5 } & Group I & Group II & Group III & Group IV \\
\hline 1 & 0.186 & 0.047 & 0.585 & 0.528 \\
2 & 0.050 & 0.028 & 0.720 & 0.370 \\
3 & 0.070 & 0.061 & 0.652 & 0.573 \\
4 & 0.140 & 0.015 & 0.339 & 0.361 \\
5 & 0.134 & 0.011 & 0.411 & 0.556 \\
6 & 0.092 & 0.048 & 0.513 & 0.342 \\
Mean(SD) & $0.112(0.051)$ & $0.035(0.020)$ & $0.537(0.145)$ & $0.455(0.108)$ \\
\hline
\end{tabular}


Table 2 Effect of Aspirin in Reducing Gastric Mucus Levels in Rats

\begin{tabular}{ccccc}
\hline & $\mathbf{n}$ & Mean (SD) & Mean Difference (CI 95\%) & P* \\
\hline Group I & 6 & $0.112(0.051)$ & $0.077(0.024-0.130)$ & 0.006 \\
Group II & 6 & $(0.0350 .020)$ & & \\
\hline
\end{tabular}

\section{Results}

The results of measurement of rat gastric mucus levels can be seen in Table 1 .

There was a significant difference in the mean of mucus level of gastric between group I and II (Table 2). This result states that induction of aspirin ( $450 \mathrm{mg} / \mathrm{kg}$ ) can decrease mucus level and create a gastric ulcer model in rats.

There was a significant difference in the mean of mucus level of gastric between group II and III (Table 3). This result state that Centella asiatica extract can prevent a declining of mucus levels of aspirin-induced gastric ulcer model in rats.

There was no significant difference in the mean of mucus level of gastric between group III and IV (Table 4). This result state that Centella asiatica extract has similar effect in preventing gastric mucus level reduction of aspirin-induced gastric ulcer model in rats with misoprostol.

\section{Discussions}

The gastric mucus is produced by epithelial cells on the surface of gastroduodenal organ. The mucus consists of water (95\%), mucin, and lipid. The functions of gastric mucus are lubricate to protect mucous from mechanical damage, protect gastric lining from self-digestion from pepsin (without disturbing the activity of pepsin) and from acid by neutralizing $\mathrm{HCl}$ (without disturbing the function of $\mathrm{HCl}$ in the lumen). ${ }^{1,11}$

This study showed that rats which received Centella asiatica extract (400 $\mathrm{mg} / \mathrm{kg}$ ) prior to administration of aspirin (450 mg/kg) for three consecutive days had mean mucus level 0.537 optical density per gram of tissue. It demonstrated that Centella asiatica extract can prevent declining of mucus levels of aspirininduced gastric ulcer model in rats $(p<0.05)$.

Centella asiatica consists of triterpenoids and flavonoids. Triterpenoid is the most common component in Centella asiatica. ${ }^{4}$ Centella asiatica has been proved to have roles as wound healing, anti-inflammatory, and antioxidant. A research of Shukla et al. stated that asiaticoside derived from Centella asiatica had a role in wound healing in vitro and in vivo. It was proved by increasing tensile strength, collagen, fibroblast proliferation, and wound epithelization in guinea pig and rat. Its role in wound healing was also proved from the increasing angiogenesis in vitro. ${ }^{12}$ The research also stated that saponin, asiatic acid, madecassoside derived from Centella asiatica had the effect of wound healing by inducing the production of collagen type I to stimulate the wound healing process. ${ }^{4}$

Normal phases of wound healing consist of hemostasis, inflammation, proliferation, and remodeling. Centella asiatica has a role in the proliferative phase. This phase is dominated by granulation tissue formation and epithelization. In this phase there will be releasing of macrophage and growth factor from platelets to stimulate migration and activating of fibroblast. Then, fibroblast will produce an important substance for wound healing. One of the substances is collagen. ${ }^{13}$

Research of Frederico et al. stated that there is a positive correlation between the flavonoids received from Centella asiatica and antioxidant. Centella asiatica can absorb or neutralize free radicals. Free radicals can damage proteins, DNA, and lipids in cell membrane. ${ }^{14}$ Research of Huang et al. stated that asiatic acid derived from Centella asiatica had the effect as antiinflammatory. Anti-inflammatory response can be seen from declining malondyaldehyde and nitric oxide levels. Both of them are produced by impact of free radicals that attack plasma

Table 3 Effect of Centella asiatica and Aspirin-induced Gastric Ulcer in Gastric Mucus Level

\begin{tabular}{ccccc}
\hline & $\mathbf{n}$ & Mean (SD) & Mean Difference (CI 95\%) & p $^{*}$ \\
\hline Group II & 6 & $0.035(0.020)$ & $0.502(0.350-0.653)$ & $<0.001$ \\
Group III & 6 & $0.537(0.145)$ & & \\
\hline
\end{tabular}


Table 4 Effect of Centella asiatica and Misoprostol in Gastric Mucus Level Induced rats

\begin{tabular}{ccccc}
\hline & $\mathbf{n}$ & Mean (SD) & Mean Difference (CI 95\%) & $\mathbf{p}^{*}$ \\
\hline Group III & 6 & $0.537 \pm 0.145$ & $0.081(0.083-0.246)$ & 0.147 \\
Group IV & 6 & $0.455 \pm 0.108$ & & \\
\hline
\end{tabular}

membrane. Anti-inflammatory response can also be seen by increasing antioxidant enzyme, e.g. catalase, superoxide dismutase (SOD), and glutathione peroxidase in liver tissue.$^{15}$ A research of Somchit et al. stated that asiatic acid and madecassic acid derived from Centella asiatica had the effect as analgesic and anti-inflammatory. ${ }^{16}$

Moreover, this study showed that Centella asiatica $(400 \mathrm{mg} / \mathrm{kg})$ had similar effect with misoprostol in preventing gastric mucus levels reduction of aspirin-induced gastric ulcer model in rats $(p \geq 0.05)$. The conclusion of this study is Centella asiatica leaves can prevent gastric mucus level reduction of aspirininduced gastric ulcer model in rats.

\section{References}

1. Valle JD. Peptic Ulcer Disease and Related Disorders. In: Fauci AS, Kasper DL, Longo DL, Braunwald E, Hauser SL, Jameson JL, et.al., editors. Harrison's Principles of Internal Medicine. 17thed. The US: McGraw-Hill Companies, Inc.; 2008. p. 1855-72.

2. Badan Pengawas Obat dan Makanan Republik Indonesia. Kriteria dan tata laksana pendaftaran obat tradisional, obat herbal terstandar dan fitofarmaka. Jakarta: BPOM; 2005.

3. Kementrian Kesehatan Republik Indonesia. Profil kesehatan tahun 2008. Jakarta: Departemen Kesehatan Republik Indonesia; 2009.

4. Winarto WP, Surbakti M. Khasiat dan manfaat pegagan tanaman penambah daya ingat. Jakarta: PT AgroMedia Pustaka; 2003.

5. Badan Tenaga Nuklir Nasional. Pedoman Etik Penggunaan dan Pemeliharaan Hewan Percobaan. Jakarta: BATAN; 2011.

6. Abdulla MA, Al-Bayaty FH, Younis LT, Hassan MIA. Anti-ulcer activity of Centella asiatica Leaf Extract Against Ethanolinduced Gastric Mucosal Injury in Rats. J Med Plant Res. 2010;4(13):1253-59.

7. Paget GE, Barnes JM. Toxicity tests.
In: Lawerence DR, Bacharach AL, editors. Evaluation of drug activities: pharmacometrics. In:. New York: Academic Press. 1964. p. 135-65.

8. Wijayani A, Ummah $\mathrm{K}$, Tjahjani S. Karakterisasi karbosimetil selulosa (CMC) dari eceng gondok Eichornia crassipes (Mart) Solms. Indo J Chem. 2005;5(3):22831.

9. Sancar M, Hantash T, Okuyan B, ApikogluRabus S, Cirakli Z, Gulluoglu MG, et al. Comparative effectiveness of Glycyrrhiza glabravs. omeprazole and misoprostol for treatment of aspirin-induced gastric ulcers. Afr J Pharm Pharmacol. 2009;3(12):61520.

10. Green AP, Lander JE, Turner DH. The Effect of Stress and indomethacin, carbenoxolone, salbutamol, metiamide, zolimidine and CF19415 on rat gastric mucus. J Pharm Pharmacol. 1981;33(6):348-52.

11. Sherwood L. Human physiology: from cells to systems. 7th ed. Canada: Brooks/Cole, Cengage Learning; 2010.

12. Shukla A, Rasik AM, Jain GK, Shankar R, Kulshrestha DK, Dhawan BN. In Vitro and In Vivo wound healing activity of asiaticoside isolated from Centella asiatica. J Ethnopharmacol. 1999;65(1):1-11.

13. MacKay D, Miller AL. Nutritional support for wound healing. Altern Med Rev. 2003;8(4):359-77.

14. Pittella F, Dutra RC, Junior DD, Lopes MTP, Barbosa NR. Antioxidant and cytotoxic activities of Centella asiatica (L) Urb. Int J Mol Sci. 2009;10(9):3713-21.

15. Huang S-S, Chiu C-S, Chen H-J, Hou W-C, Sheu M-J, Lin Y-C, et al. Antinociceptive activities and the mechanisms of antiinflammation of asiatic acid in mice. Evid Based Complement Alternat Med. 2011:2011;895857.

16. Somchit MN, Sulaiman MR, Zuraini A, Samsuddin L, Somchit N, Israf DA, et al. Antinociceptive and Antiinflammatory Effects of Centella asiatica. Indian J Pharmacol. 2004;36(6):377-80. 